\title{
The Perspective of Islamic Law on a Mismatched Object in Online Sales and Purchases Transactions
}

\author{
Intan Mukarromah Mustikawati \\ University of Jember, Indonesia \\ intanmukarromahmustikawati25@gmail.com
}

\author{
Mardi Handono \\ University of Jember, Indonesia \\ mardihandono36.fh@unej.ac.id
}

Emi Zulaika

University of Jember, Indonesia

emizulaika@ymail.com

\begin{abstract}
Online transaction is a cross-personal action done by two or more parties to reach an agreement. The law of sales and purchases in Islam requires the double coincidence of wants as a measure of transaction validity. However, humans will always find the double coincidence of wants as a remote probability. Therefore, the previous Ulamas set an ijab-qabul as a symbolization of the double coincidence of wants. A qabul is an expression of the handed over of one's ownership rights to a particular party, and vice versa, as well as a sign that both of the parties have agreed on the contract ( $\mathrm{k} k \mathrm{ad}$ ).
\end{abstract}

KEYWORDS: Online Transactions, Buying and Selling in Islamic Law, Object Mismatches.

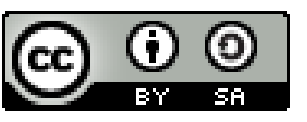

Copyright $\odot 2019$ by Author(s)

This work is licensed under a Creative Commons Attribution-ShareAlike 4.0 International License. All writings published in this journal are personal views of the authors and do not represent the views of this journal and the author's affiliated institutions.

\section{HOW TO CITE:}

Mustikawati, Intan Mukarromah, Mardi Handono \& Emi Zulaika. "The Perspective of Islamic Law on a Mismatched Object in Online Sales and Purchases Transactions" (2019) 6:2 Lentera Hukum $225-234$

Submitted: May 15, 2019 Revised: June 09, 2019 Accepted: July 13, 2019 


\section{INTRODUCTION}

Indonesia is the world's most populous Muslim majority country. The Shari'a-based economy was enforced in accordance with Islamic law to achieve the maximum wellbeing of the people. Islamic law is based on the belief that Allah has determined both resources and regulations for His umat (followers). Shari'a also covers a law of God relating to adults' practice and behavior (mukallaf), which are laws consisting of matter halal, haraam, sunnah, rightful, and makruh.These decisions become fiqih and later becomes interpreted as established law. Islam also regulates trade in the Law of Mualamah where the law arranges human relations, whether done individually or collectively between nations or between worshipers, such as contracts, spending, punishment, and jinayat.

According to Mualamah, sales and purchases are forms of freedom and autonomy from Allah. These are determined as endless necessities because humans will continue to exist and as a result have needs. ${ }^{2}$ There is great variety between Ulamas on what is considered halal. The determinations must be bound with nash (texts) based on ijtihad. ${ }^{3}$ Sales and purchases in Islam, according to Malikiyah Ulama, Syafi'iyah and Hambaliyah, is defined as"exchanging assets in the form of transfer of property and ownership." ${ }^{4}$ According to the Hanafiyah Ulama, sales and purchases are defined as "exchanging assets in certain ways." An online transaction is the same as a contract of ordering (akad salam) which was initially prohibited because it is a transaction of intangible goods (ba'iul ma'dum). However, a wide range of human needs for this akad salam is permissible because of the existence of purpose (hajat). ${ }^{6}$

These selling-and-buying transactions are increasing, as electronic transactions and e-commerce become pervasive. E-commerce introduces complication to Islamic Law because there is not a direct meeting between the sellers and the buyers.. ${ }^{7}$ Because transactions are only online, the transactions are susceptible to fraud.For example, posts can offer inaccurate pictures to the goods sold, mismatched quality with specifications of goods in the description, , andpossible damages and defects that can harm the buyers.

\footnotetext{
Masykuri Abdillah, dkk, Formalisasi Syariat Islam di Indonesia, Jakarta: Renaisan, 2005 at 13. http://idr.uin-antasari.ac.id/8790/3/BAB\%20I.pdf accessed on October 4th, 2018 at 12:35.

Nurul Hak, Ekonomi Islam Hukum Bisnis Syari'ah, Bank Islam, Bunga Uang dan Bagi Hasil, Wakaf Uang dan Sengketa Ekonomi Syari'ah, Yogyakarta: Teras, page 209.

M. Noor Harisudin, Fiqh Muamalah 1, Jember: Pena Salsabila, 2014 at 23.

Ibid.

M. Noor Harisudin, Masa'il Fiqhiyyah, Jember: Pustaka Radja, 2015 at 9.

Ibid.
} 


\section{AN OVERVIEW OF ISLAMIC LAW ON A MISMATCHED OBJECT IN ONLINE SALES AND PURCHASES TRANSACTIONS}

For many Muslims, Islamic law can be a reflection of their behavior in society.. ${ }^{8}$ It is also viewed as a representation of perfect faith and Islam. Islamic Shari'a also includes moral and ethical Islamic jurists such as Imam Shafi'i codify these aspects through the rules of al-Alkam al-Khamsah (five types of the legal regulations) which include the matter of mubah, sunnah, makruh, obligatory, and haraam. ${ }^{9}$ Honest and fair sales and purchases transactions are emphasized in a trade or bai' in Al-Quran and by the teachings of Prophet Muhammad. In Islamic law, after a halal transactions ocurrs, one then arranges for an akad (contract) agreed upon by both parties. Akad is consent in an agreement between two or more parties. ${ }^{10}$

In Islam, this trade existed since the era before Prophet Muhammad sallallaahu alaihi wa sallam was being appointed as an Apostle. The Prophet Muhammad ordered merchants to make good, honest, and fair tradse. Technology complicates commerce now because sellers often take advantage of situations to swindle consumers. Sales, purchases, and contracts deemed prohibited (declared as haraam) by the Prophet Muhammad are robbery, exploitation, fraud, embezzlement, , injustice, gambling, coincidence, or dishonesty. ${ }^{11}$ The inconsistency of objects in online trade in Islam is also called Gharar trading-all types of sales and purchases transactions which are done by tricking other parties. Gharar in Arabic means al-khathr (betting), majhul al-aqibah (unclear results), and can also be interpreted as al-mukhatharah (gambling), and aljahalah (obscurity). ${ }^{12}$ Gharar is a form of doubt, deception, or betrayal, and an action that can harm others. The prohibition can be found in the Qur'an Surah Al-Muthaffifin [1-3], which stated that significant punishment for those who cheat, (i.e.) people "who, when they take a measure from people, take in full; but if they give by measure or by weight to them, they cause loss." Thus, mismatching object descriptions with the actual object can be considered gharar and is thus prohibited in Islamic law.Furthermore, sellers must agree to replace damaged goods after shipment. This fulfils the requirement of having an akad, or contract, and thus would be halal.

According to Hanafi scholars, akad fasid is a contract which is in principalallowed, but invalid by its nature. The point is that the deal has fulfilled the pillars and the requirements of its formation but have not met the requirements of its validity. Fasid contract is distinguished with the batil agreement because it is not valid either in its principal or in its nature. In other words, there are only nonphysical objects included in

Al-Subki, al-Syais, al-Barbari (2001 M/1421 H), Tarikh a-Tasyri'al Islami, Second Edition. Damakus: Dar al-'Ashama' at 22-25.

9 Hazairin, Tujuh Serangkai Tentang Hukum Islam, Jakarta: Tintamas, 1974 at 72.

10 Article 20 No. 1 Book II concerning Contract, Compilation of Sharia Economic Law.

1l Muhammad Sharif Chaudhry, Sistem Ekonomi Islam: Prinsip Dasar, Jakarta: Prenadamedia Group, 2012 at $125-126$.

12 Nadratuzzarna Horsen, Analisis Bentuk Gharar Dalam Transaksi Ekonomi, Jurnal Fakultas Syariah dan Hukum Jakarta at 54 . 
the transaction. ${ }^{13}$ Despite that, Sunni jurists do not distinguish the batil from the fasid. For them, both of these things have the same meaning-both are illegitimate contracts consisting of immaterial goods and do not have different legal consequences. Objects can be perceived as sacred if their type, quality, quantity, amount of price, and form have been known since the very beginning. Knowledge of the goods is intended to avoid the elements of al-qarar or fraud so that the products that have been traded can be handed over and will belong to the party entitled to have the products. ${ }^{14}$ The Prophet sallallaahu alaihi wa sallam once stated, "Whoever deceives, then he is not of our people. People who commit treason and deception, their place is in hell" (Narrated by Ibn Hibban).

Knowledge of goods must be taken into account. Accordingly, some scholars categorize it as a legitimate condition for a selling and buying transaction. In fiqih terminology, this form of online trade is termed as bai' al-ma'dum, which means sales and purchases activities of unphysical objects. There are two types of bai 'al-ma'dum. The first is that the object can be ascertained. Ibn Taymiyyah and Ibn Qayyim al-Jauziyah allowed this type, for example, the sales and purchases of houses in residential locations. In the Qur'an, the hadiths and sayings of the Companions did not prohibit this matter. There is, however, a prohibition on gharar trading where the transactions are speculative; this is when there is no guarantee of the availability of the goods. Ibn Qudamah said that the legal causality does not lie in the presence or the absence of an item but in the certainty of whether or not there is an item. If not, this can be said as gharar, which will be forbidden. ${ }^{15}$ While the second type of bai' al-ma'dum is that if the goods cannot be ascertained, this type has been agreed to be prohibited.

In fiqh discourse, this type of sales and purchases is known as al-salam or al-salaf, which is a type based on the way of ordering. The Fiqh scholars define it as the activity of selling an item whose submission is postponed, or selling an item whose characteristics are precise with earlier capital payments, while the goods are delivered later. A salam contract is a sales and purchases transaction in the form of an order or an item with certain criteria whose price must be paid in cash at the time of the contractl6 and can be finalized with transparent terms and conditions of quality, measurable weights, and the specifications of the ordered goods must be known certainly by the parties. 17 To be sufficient with the rules, these are also permitted in a manner of syar'i (Islamic law), istihsan (assuming good), and 'urf (custom/habit). The Prophet said: "If you make buying and selling greetings, then do it in a certain size, a certain scale and a certain time." (Narrated by Bukhari-Muslim, Abu Daud, an-Nasa'i, at-Tirmidzi, and Ibn Majah of Abbas).

\footnotetext{
13 Ibn Nujaim al-Mishri, al-Asybah wa an-Nazha'ir,Beirut: Dar al-Kutub al-'Ilmiyyah, 1985 at 337.

14 M. Quraisy Shihab, Secercah Cahaya Al-Qur'an, Bandung: Mizan at 240.

15 Ibnu Qudamah al-Maqdisi, Al-Mughni, Mesir: Maktabah al-Jumhuriyyah al-'Arabiyyah at 208.

16 Fatwa DSN-MUI No.110/DSN-MUI/IX/2017 regarding Sale and Purchase Agreement Chapter 1, at 15.

17 Article 101 Book II concerning Contract, Compilation of Sharia Economic Law.
} 


\section{THE FORMS OF DISPUTE SETTLEMENT EFFORTS FOR MISMATCHED PRODUCTS IN ONLINE TRADING}

The business and economic fields have fundamental differences for legal institutions caused by an inadequate set of norms to support such rapid business and commercial activities. Judicial institutions are deemed ineffective and inefficient in examining, hearing, and resolving the proposed business disputes because they are not familiar with complicated and lengthy business disputes. ${ }^{18}$

Consumers, as one of the parties to the transaction, often feel disadvantaged by the actions of business actors who do not fulfill their demands and obligations. Consumers who are feeling disadvantaged have the option to sue the business actor through an institution.. Within this process, both sides can agree to a settlement that opens up the possibility for the parties to peacefully compromise before submitting the case to the court. Regarding the reconciled disputes, dispute resolution sometimes requires particular objects to achieve peace, for example, in terms of compensation that must be in accordance with the amount of losses suffered by customers .

In an effort to protect consumers, a national consumer protection agency has been formed, notably Badan Perlindungan Konsumen Nasional (BPKN). BPKN was established as an effort to develop consumer protection in terms of regulating the rights and obligations of consumers and business actors, regulating rights and prohibitions for business actors, controlling the responsibilities of business actors, and regulating consumer dispute resolutions. BPKN is an independent body which has a direct connection to the president. BPKN is expected to provide maximum protection. the $\mathrm{BPKN}$ also gives advice and consideration to the government in developing consumer protection efforts.

There are two ways of settling the disputes: through the courts (litigation) and outside the courts (non-litigation). Non-litigation in dispute resolution focuses on reaching an agreement on the form and amount of compensation or specific actions to guarantee that there will be no repetition of the losses suffered by consumers. The kind of the guarantee referred, in this case, is in the way of a written statement explaining that there will be no recidivism of actions that are detrimental to the consumer. The measure of the material loss experienced by consumers is based on the magnitude of the impact of using the product or the service product on consumers. Consumer dispute resolution outside the court can be made through the official consumer dispute settlement agency or Badan Penyelesaian Sengketa Konsumen (BPSK), nongovernmental consumer protection agency or Lembaga Perlindungan Konsumen Swadaya Masyarakat (LPKSM), and the other dispute resolution institutions in accordance with the agreement of the two disputing parties.

The Government established a consumer dispute settlement body in the second level region (Daerah Tingkat II) to resolve consumer disputes outside the court ${ }^{19}$, which

\footnotetext{
18 Eman Suparman, Pilihan Forum Arbitrase dalam Sengketa Komersial untuk Penegakan Keadilan, Jakarta: Tatanusa, 2004 at 3.

19 Article 49 paragraph 1 of Act Number 8 of 1999 on Consumer Protection.
} 
is BPSK. According to Article 1 of the Consumer Protection Law, its task is to resolve conflicts between business actors and consumers. This body is a small court which will be responsible for conducting a trial paired with quickly generated decisions with a low cost in accordance with the principle of justice. ${ }^{20}$ Every consumer who feels aggrieved by a business actor can complain about his/her problem verbally or orally, directly or indirectly, to BPSK by being represented by his proxy or by his heirs if the consumer is sick, dead, whether the consumer is an elderly, an under-age, or a foreign citizen. Still, peaceful resolution without going through a court is highly recommended for the disputing parties. A peaceful can be accomplished by business actors and consumers without going through a court or the consumer dispute resolution agency and not in violation of the consumer protection law. ${ }^{21}$

BPSK carries out its duties with the assistance of its secretariat. The appointment and dismissal of the head of the secretariat and members of the BPSK secretariat are determined by the minister. ${ }^{22}$ Considering its task, which is resolving disputes between consumers, the institution seems to function as a consumer defense institution and ultimately creates reluctance or dissatisfaction from producers or sellers in resolving consumer disputes. Therefore, the dispute resolution body is more appropriate if it stands independently. The decision of BPSK is final, binding, and without any appeal, because BPSK is an institution outside the court.

Although there are many non-litigation ways to resolve disputes, there are other ways such as arbitration, conciliation, and mediation.

a) Arbitration is a civil settlement method which is based on an arbitration agreement made by the disputing parties. Settlement can be executed if the parties have included the arbitration clause in the contract which became the subject of the dispute or submitted into an arbitration agreement after the dispute arose between them. Arbitration is done thoroughly by an assembly acting as arbitrator. By doing arbitration, the parties choose the arbitrator from BPSK members who come from elements of business actors and consumers as members of the assembly. After being elected, the chairperson of the assembly in the trial must provide instructions to consumers and business actors regarding legal remedies used in resolving disputes. The advantage in doing arbitration is that it offers a final decision, and it has a permanent and binding legal force. This arbitration decision has executorial power, which means that if the defeated party does not fulfill the decision voluntarily, the winning party can request execution to the court. ${ }^{23}$

b) Conciliation is a process of resolving consumer disputes through non-litigation mechanism with BPSK as an intermediary to gather the disputing parties and lead them towards their satisfactory agreement. This conciliation is also possible as an

20 Hanief Rizki Utomo, Perlindungan Hukum Terhadap Konsumen Online Merima Kerusakan Barang Diakibatkan Oleh Kelalalian Jasa Pengiriman Barang PT. Tiki Jember, Thesis, Faculty of Law Universitas Jember, 2016 at 47.

21 Ahmadi Miru dan Sutarman Yodo, Hukum Perlindungan Konsumen, Jakarta: Rajawali Pers, 2011 at 224.

22 Article 51 of Act Number 8 of 1999 on Consumer Protection.

23 Ibid at 250. 
alternative to consumer dispute resolution under the consumer protection law. This method includes neutral and impartial third parties. The conciliator is only responsible in arranging the place and time of the meeting of the parties, directing the subject of the conversation, and bringing a message from one party to another if it is not possible to be delivered directly. The conciliator from BPSK can propose a dispute resolution but cannot put any final decision on the case. This is because conciliation model refers to the pattern of a consensual settlement process between parties where neutral parties only play a passive role. The results of the deliberations between consumers and business actors in the subsequent disputes are made in the form of a written agreement signed by the parties and submitted to the panel to be stated in the BPSK assembly's decision that strengthens the deal.

c) Mediation is another non-litigation process of resolving consumer disputes with BPSK as an advisor. Mediation is an alternative dispute resolution that is well known in Indonesia and is also one of the best choices between the existing Alternative Dispute Resolution (ADR) systems and forms. Mediation must be preceded by the consensus of the parties to resolve disputes through the mediation itself, to undergo a dispute resolution negotiation process with impartial third parties, and to cooperate with the parties to reach the optimal solution. The dispute resolution is entirely the responsibility of the disputing parties. This includes of determining the form and amount of compensation or other actions to ensure that the consumer's losses will not happen again in the future. The role of the mediator is to help the parties to find a way out of the disputes so that the results are entirely dependent on the parties' opportunities. The results, in the form of compromise, are not binding. Instead, the results depend on voluntary actions and good faith of each party to fulfill the outcome of a settlement. ${ }^{24}$

It was stated that not the entire models of non-litigation dispute resolutions or alternative solutions are suitable for the disputing parties. An excellent alternative dispute resolution must at least fulfill the following principles: ${ }^{25}$

a) Time-efficient;

b) Cost-saving;

c) Accessible;

d) Protect the rights of the disputing parties;

e) Result in fair and honest decisions;

f) Trustworthy;

g) Have a final and binding decision;

h) Have an effective decision (easy to implement);

i) Have a decision which is in accordance with the standard of justice within the community where the dispute resolution is conducted.

24 Yahya Harapan, Beberapa Tinjuan Mengenai Sistem Peradilan dan Penyelesaian Sengketa, Bandung: Citra Aditya, 1997 at 194.

25 Susanti Adi Nugroho, Proses Penyelesaian Sengketa Konsumen Ditinjau darai Hukum Acara Serta Kendala Implementasinya, Jakarta: Kencana, 2008 at 101. 
LPKSM is also a non-governmental institution for consumer protection which has been registered and recognized by the government. This institution must gain registered recognition from the district/city government, which is engaged in consumer protection, as stated in its articles of association. The registration is only intended as a data gathering and is not a permit. Besides that, LPKSM is also burdened with the obligation to report its implementation to the city/regency official every once a year.

Consumer dispute resolution is generally included in the category of civil law, albeit it also can be under criminal offenses (economy). In civil cases, law enforcement procedures start from receiving a lawsuit or request until the execution of a decision. Therefore, in addition to containing the provisions regulating how to litigate before the trials, the civil procedure law also determines how to guarantee the implementation of its material law. ${ }^{26}$

The trial is a fardhu kifayah for the sake of people's well-being. Therefore, ulil amri or the government must establish a judicial authority through the appointment of a qidhi or a judge to enforce the law in the country. Lawsuits through the courts can only be reached if a non-litigation dispute resolution effort has not been reached or failed. A court which has the authority to resolve consumer disputes is a public court-even supposing that authority can also be the authority of the religious court. Religious court, along with the growing practice of economics and Islamic business, experienced an expansion of authority; having the duty and authority to examine, decide, and settle cases in the first level between people who are Muslim in the fields of marriage, will, grants, endowments, zakat, infaq, and economic shari'a. ${ }^{27}$ However, if there is a dispute between the two Muslim parties, the matter is resolved through Badan Arbitrase Syariah (Sharia Arbitration Board) after a failed compromise or dialogue. ${ }^{28}$

In the view of fiqh, such legal products can be categorized as a result of ijtihad as long as their existence brings welfare over its direct or indirect establishment process and refers to the Qur'an and the Sunnah. Therefore, business actors, as the servants of God, should reflect the provisions revealed in the Surah An-Nisa [59]: "Believers! Obey Allah and obey the Messenger, and those from among you who are invested with authority (ulil amri); and then if you were to dispute among yourselves about anything refer it to Allah (Al-Qur'an) and the Messenger (sunnah) if you indeed believe in Allah and the Last Day; that is better and more commendable in the end."

\section{CONCLUSION}

Object mismatches in online sales and purchases transactions in the perspective of Islamic law are transactions that offer a new application of Islamic laws regarding trade. Principally, online sales and purchases transaction is lawful even though prospective buyers cannot see the traded goods directly. In order for online sales to be

\footnotetext{
26 Ibid.

27 Article 49 of Law No. 3 of 2006 concerning Amendments to Law No. 7 of 1989 concerning Religious Courts.

28 Fatwa DSN-MUI Nomor 05/DSN-MUI/IV/2000 regarding Salam Sale and Purchase.
} 
halal, they must be copled with as promised services and agreements to return defective or damaged items.. The abkad is also still valid because it has fulfilled the Pillars as well as the requirements of its formation and validity. Nonetheless, sale and purchase that contains elements of fraud and betrayal, either because of the obscurity of the object or the uncertainty in its integrity are against Islamic law.. As this prohibition directly contradicts the essence of sales and purchases as defined in Islamic law, such transactions are considered illegal and illegitimate.

The form of dispute resolution efforts in online sales and purchases transactions was included in Article 45 of consumer protection laws regarding consumer dispute resolution options, There are two mane options, those done through court mechanisms (litigation) and those doneoutside court mechanisms (non-litigation) based on the voluntary choices of the disputing parties. A non-litigation dispute resolution or alternative dispute resolution can be reached by arbitration, mediation, and conciliation: these depend on the parties' agreement to settle the dispute. Peaceful settlement outside the court offers characteristics, which are guaranteeing confidentiality, involving experts in the field, providing fast and simple procedures, time efficiency, cost-effectivity, final and binding decisions, offering decisions which are not published without the parties' permission, as well as offering honest and fair decisions.

\section{REFERENCES}

Masykuri Abdillah, et al. 2005. Formalisasi Syariat Islam di Indonesia. Jakarta: Renaisan.

Abd. Shomad. Hukum Islam: Penormaan Prinsip Syariah Dalam Hukum Indonesia. Jakarta: Kencana.

Nurul Hak. Ekonomi Islam Hukum Bisnis Syari'ah, Bank Islam, Bunga Uang dan Bagi Hasil, Wakaf Uang dan Sengketa Ekonomi Syari'ah. Yogyakarta: Teras.

M. Noor Harisudin. 2014. Fiqh Muamalah 1. Jember: Pena Salsabila.

M. Noor Harisudin. 2015. Masa'il Fiqhiyyah. Jember: Pustaka Radja.

Al-Subki, al-Syais. al-Barbari (2001 M/1421 H. Tarikh a-Tasyri'al Islami. Second Edition. Damakus: Dar al-'Ashama'.

A. Djazuli. 2005. Ilmu Fiqh cetakan V. Jakarta: Kencana Prenada Media Group.

Hazairin. 1974. Tujuh Serangkai Tentang Hukum Islam. Jakarta: Tintamas.

Muhammad Sharif Chaudhry. 2012. Sistem Ekonomi Islam: Prinsip Dasar. Jakarta: Prenadamedia Group.

Nadratuzzarna Horsen, Analisis Bentuk Gharar Dalam Transaksi Ekonomi, Jurnal Fakultas Syariah dan Hukum Jakarta,

Ahmad Sarwat. Fikih Sehari-Hari. Jakarta: Penerbit Kadil.

Ibn Nujaim al-Mishri. 1985. al-Asybah wa an-Nazha'ir. Beirut: Dar al-Kutub al-'Tlmiyyah.

M. Quraisy Shihab. Secercah Cahaya Al-Qur'an. Bandung: Mizan

Mardani. 2011. Hukum Ekonomi Syariah Di Indonesia, Bandung: PT Refika Aditama. 
Ibnu Qudamah al-Maqdisi. Al-Mughni, Mesir: Maktabah al-Jumhuriyyah al-'Arabiyyah. Eman Suparman. 2004. Pilihan Forum Arbitrase dalam Sengketa Komersial untuk Penegakan Keadilan. Jakarta: Tatanusa.

Hanief Rizki Utomo. 2016. Perlindungan Hukum Terhadap Konsumen Online Merima Kerusakan Barang Diakibatkan Oleh Kelalalian Jasa Pengiriman Barang PT. Tiki Jember. Thesis Faculty of Law Universitas Jember.

Ahmadi Miru dan Sutarman Yodo, Hukum Perlindungan Konsumen. 2011. Jakarta: Rajawali Pers.

Ahmadi Miru. 2000. Prinsip-Prinsip Perlindungan Hukum bagi Konsumen di Indonesia. Dissertation, Postgraduate Program Universitas Airlangga. Surabaya.

Yahya Harapan. 1997. Beberapa Tinjuan Mengenai Sistem Peradilan dan Penyelesaian Sengketa, Bandung: Citra Aditya.

Susanti Adi Nugroho. 2008. Proses Penyelesaian Sengketa Konsumen Ditinjau darai Hukum Acara Serta Kendala Implementasinya. Jakarta: Kencana.

http://idr.uin-antasari.ac.id/8790/3/BAB\%20I.pdf accessed on October 4th, 2018 at 12:35.

Law Number 8 of 1999 concerning Consumer Protection.

Law Number 3 of 2006 concerning Amendments to Law Number 7 of 1989 concerning Religious Courts.

Fatwa DSN-MUI Nomor 05/DSN-MUI/IV/2000 regarding Salam Sale and Purchase.

Fatwa DSN-MUI No.110/DSN-MUI/IX/2017 regarding Sale and Purchase Agreement.

The Supreme Court of the Republic of Indonesia, Regulation Number 2 of 2008 concerning Compilation of Sharia Economic Law book II on Contracts. 